\title{
The Incidence of Repeat Breeding in Dairy Cows under Tropical Condition
}

\author{
M. Yusuf*, L. Rahim, M. A. Asja, \& A. Wahyudi \\ Department of Animal Production, Faculty of Animal Science Hasanuddin University \\ Jln. Perintis Kemerdekaan Km 10 Makassar 90245, Indonesia \\ (Received 28-07-2011; accepted 01-02-2012)
}

\begin{abstract}
ABSTRAK
Penelitian ini bertujuan untuk mempelajari tingkat kejadian kawin berulang pada ternak sapi perah di daerah tropis. Penelitian ini merupakan studi awal yang dilaksanakan di Kabupaten Sinjai, Indonesia. Sebanyak 82 ekor ternak sapi perah pada lima kelompok tani/ternak digunakan dalam penelitian ini. Sebanyak $75,6 \%$ dari 82 ternak sapi perah mengalami kebuntingan setelah beberapa kali dilakukan inseminasi buatan (IB). Tingkat kejadian kawin berulang pada daerah ini sangat tinggi (62\%). IB pertama setelah melahirkan, angka konsepsi pada IB pertama, dan jarak antara melahirkan dan kembali bunting adalah 62,5 $\pm 15,2$ hari, $0 \%$, dan 202,8 150,0 hari. Hasil penelitian menunjukkan bahwa tidak terdapat perbedaan yang nyata antara ternak yang kawin berulang dan yang normal terhadap IB pertama setelah melahirkan $(60,4 \pm 15,2$ hari vs $68,3 \pm 28,6$ hari). Namun demikian, ternak sapi perah dengan fertilitas normal hanya membutuhkan 123,3 $\pm 52,9$ hari untuk kembali bunting dan $2,4 \pm 0,8$ kali inseminasi per kebuntingan, sedangkan ternak kawin berulang membutuhkan lebih banyak waktu $(222,9 \pm 134,1$ hari) untuk kembali bunting dan inseminasi per kebuntingan $(4,8 \pm 0,9$ kali). Sebagai kesimpulan adalah bahwa penampilan reproduksi ternak kawin berulang sangat rendah sehingga menurunkan penampilan reproduksi ternak secara keseluruhan.
\end{abstract}

Kata kunci: sapi perah, tropis, kawin berulang, penampilan reproduksi

\section{ABSTRACT}

The objective of this study was to investigate the incidence of repeat breeding in dairy cows under tropical condition. This was a preliminary study conducted in Sinjai Regency, Indonesia. A total of 82 Holstein Friesian lactating cows from five dairy farmer groups were used in the present study. Of the 82 cows, $75.6 \%$ eventually became pregnant after repeated inseminations (AI). The incidence of repeat breeding in this area was very high (62\%). Days in milk (DIM) at first AI, first AI conception rate, and calving to conception interval were $62.5 \pm 19.3$ days, $0 \%$, and $202.8 \pm 150.0$ days, respectively. There was no difference in DIM at first AI between repeat breeders and normal fertility cows (60.4 \pm 15.2 days vs $68.3 \pm 28.6$ days). However, normal fertility cows required only $123.3 \pm 52.9$ days to conceive and $2.4 \pm 0.8$ inseminations per pregnancy, whereas repeat breeders required significantly more days to conceive $(222.9 \pm 134.1$ days) and more inseminations per pregnancy $(4.8 \pm 0.9)$. In conclusion, repeat breeder dairy cows under tropical condition had very poor and reduced reproductive performance.

Key words: dairy cows, tropical condition, repeat breeding, reproductive performance

\section{INTRODUCTION}

One of the important reproductive disorders in dairy cattle is repeat breeding, in which, high incidence of this reproductive disorder resulting in economic loss in dairy herds (Katagiri \& Takahashi, 2004). The incidences of repeat breeding have been reported vary

* Corresponding author:

E-mail: ramadhanti_yusuf@yahoo.com in several studies, ranging from $5 \%$ to $30 \%$ (Bulman \& Lamming, 1978; Bartlett et al., 1986; Bage et al., 2002; Moss et al., 2002; Yusuf et al., 2010a). Causes of this repeat breeding are usually unclear, but probably include environmental, management, and animal factors (Katagiri \& Takahashi, 2004). For example, there have been changes in animal's environment, e.g. the genetic potential for milk yield has improved, the herd size of dairy farms has been expanding, the housing system of dairy cattle has been changing from tie stall to free stall, and total mixed ratio (TMR) feeding systems have 
become widespread (Nakada, 2006). However, it is not clear whether the animals have adapted adequately to these environmental changes. These all are subsequently affecting the reproductive efficiency in dairy cattle.

Likewise, climate factor, for example, during summer and tropical condition there was a reduction in fertilization rate (Sartori et al., 2002). This detrimental effect is augmented by increased heat stress in lactating cows. Reduction in fertilization rate during heat stress appear to be due to an oocyte problem (Britt, 1994) based on the finding of numerous accessory sperm in the zona pellucida of unfertilized ova (Sartori et al., 2002), resulting in an increased number of services per conception (Macmillan et al., 1996; Roche et al., 2000; Royal et al., 2000; Lucy, 2001). Consequently, the incidence of repeat breeding should have increased (Dochi et al., 2008; Yusuf et al., 2010a). To our knowledge, most reports of repeat breeding in dairy cows based on subtropical condition, but lacked information regarding the incidence of repeat breeding in tropical condition. Therefore, the objective of this study was to investigate the incidence of repeat breeding in dairy cows under tropical condition.

\section{MATERIALS AND METHODS}

\section{Data Collection, Animal and Herd Management}

This study was conducted in Sinjai Regency; south-eastern South Sulawesi Province, Indonesia during a period of two months (October-November 2010). All data included reproductive performance such as days in milk (DIM) at first AI, First AI conception rate (FAICR), number of days from calving to conception, and number of services per conception (S/C) were collected from the farmers and inseminators with the help of a questionnaire. A total of 82 Holstein Friesian lactating cows (randomized sampling at approximately $35 \%$ of the total population) with parities one to three from five dairy farmer groups were used in the present study. In order to meet the tropical condition, all cows' reproductive parameters were calculated based on the condition of animals throughout the year. Cows were raised with small holder dairy farmers system. All herds were housed in tie-stall barns with concrete floor. The herd size ranged from 3-25 animals. Feedstuffs consisted of natural grass or king grass, rice straw, concentrate, and irregularly mineral supplements due to limitation of farmer's understanding. In all herds, no estrus/ovulation synchronization programs were used. Animals were artificially inseminated approximately within 12 $h$ by inseminator after detection of estrus by the owners using frozen/thawed semen of proven sires.

\section{Definition of Repeat Breeder and Reproductive Performance}

A repeat breeder was defined as an animal which did not become pregnant after three inseminations, despite no clinically detectable reproductive disorders (Yusuf et al., 2010a), otherwise, animals conceived within three inseminations were considered normal fertility (Yusuf et al., 2010b). The following reproductive end points were used to characterize reproductive performance: 1) DIM at first AI: number of days from calving to first $\mathrm{AI}$; 2) first $\mathrm{AI}$ conception rate (FAICR): number of cows that conceived at first AI, divided by number of cows which received first $\mathrm{AI} ; 3$ ) calving to conception interval: number of days from calving to conception; and 4) S/C.

\section{Statistical Analyses}

Days in milk at first AI, calving to conception interval, and service per conception were analyzed using one-way ANOVA. Chi-square analysis was used to compare first AI conception rate and cows conceived within 350 days postpartum between normal fertility cows and the repeat breeders. All calculations were performed using the statistical package SPSS 12.0 for windows (SPSS Inc., Chicago, IL, USA).

\section{RESULTS AND DISCUSSION}

\section{The Incidence of Repeat Breeding in Small Holder Dairy Farmers}

Incidences of repeat breeding in lactating dairy cows varied among regions, environments, and management (Yusuf et al., 2010a). In the present study, under tropical condition and in the small holder dairy farmers system, the incidence of repeat breeding was very high and reached at average of $62 \%$ in all herds. In comparison, several studies have reported the incidences of repeat breeding in dairy cows (Table 1 ).

Causes of this high incidence of repeat breeding in the present study were yet remain unclear. Future studies are needed to find out the causes, and in turn, conducted necessary treatments in order to improve the reproductive performance in small holder dairy farmers system. Silvia (1994) stated that there are many factors

Table 1. Summary of selected references on the incidences of repeat breeding in dairy cows

\begin{tabular}{lc}
\hline Reference & Incidence (\%) \\
\hline Bulman \& Lamming, 1978 & 8.9 \\
Bartlett et al., 1986 & 24.0 \\
Bage et al., 2002 & 10.0 \\
Moss et al., 2002 & \\
Total & 29.5 \\
Primiparous cows & 31.7 \\
Multiparous cows & 28.5 \\
Yusuf et al., 2010a & \\
Total & 14.0 \\
Parity 1 & 19.4 \\
Parity 2 & 12.2 \\
Parity 3 & 9.8 \\
Range among herds (Nine herds) & $5-24$ \\
Present study & 62.0 \\
\hline
\end{tabular}


Table 2. Reproductive performance of dairy cows with varying types of fertility in five dairy farmer groups in Sinjai Regency, 2010

\begin{tabular}{lccc}
\hline & Normal fertility & Repeat breeding & P-value \\
\hline No. of cows & 31 & 51 & - \\
Days in milk at first $\mathrm{AI}^{1}$ (range) & $68.3 \pm 28.6$ & $60.4 \pm 15.2$ & $>0.05$ \\
& $(20-120)$ & $(27-93)$ & - \\
First AI conception rate $^{2}(\%)$ & 0 & 0 & $<0.01$ \\
Cows conceived $\leq 350$ days postpartum (\%) $^{3}$ (days) (range) & 100 & $222.9 \pm 134.1$ & $<0.01$ \\
Calving to conception interval & & $(120-855)$ & $<0.01$ \\
Service per conception $(\mathrm{S} / \mathrm{C})$ & $(63-289)$ & $4.8 \pm 0.9$ & $< \pm 0.8$ \\
\hline
\end{tabular}

Note: Numbers with variability are mean $\pm \mathrm{SD}$; $\mathrm{SD}=$ Standard deviation; ${ }^{1}$ Number of days from calving to first $\mathrm{AI} ;{ }^{2} \mathrm{Number}$ of cows conceived at first AI divided by number of cows which received first AI; ${ }^{3}$ Number of days from calving to conception.

can contribute to the repeat breeder syndrome, and then it is difficult to make any generalizations as predominant causes. Basically, repeat breeder cows are subject to the same problems of fertilization failure and embryonic mortality (Silvia, 1994). A more detailed classification of repeat breeding based on pathological and managerial causes: 1) congenital or genetic anatomical defects of genital tracts, 2) congenital, genetic or acquired defects of the ova, spermatozoa or early zygote, 3) infectious or traumatic inflammatory processes, 4) endocrine dysfunction, and 5) managerial and nutritional deficiencies (Roberts, 1986). Moreover, Katagiri \& Takahashi, (2004) stated that causes of infertility in repeat breeder cows are usually unclear, but probably include environmental, management, and animal factors. Therefore, it is important to identify causes of repeat breeding to deal with this problem. The incidence of repeat breeding will be increased by inadequate estrous detection (Heuwieser et al., 1997; Pursley et al., 1998) resulting in errors in timing of insemination in relation to the onset of standing estrus, or insemination of cows not in estrus (Yusuf et al., 2010a). The other potential factors were also suggested, such as quality of semen and insemination technique (Hallap et al., 2006; Morrel, 2006), uterine and/or cervical/vaginal infections (Moss et al., 2002), endocrine disorders (Gustafsson, 1998; Bage et al., 2002; Lopez-Gatius et al., 2004), ovulation failures (Kimura et al., 1987; Silvia, 1994), obstructed oviducts, defective ova, anatomical defects of reproductive tract (Silvia, 1994), and early embryonic death (Gustafsson, 1998; Bage et al., 2002). For generally animal factors, Yusuf et al. (2010a) reported that lower parity, abnormal resumption of postpartum ovarian cycles, and shorter days in milk at first AI were the risk factors for repeat breeding. Furthermore, increased capability of milk production has been associated with a reduced of fertility in lactating dairy cows (Butler, 2000), through changes in reproductive physiology (Wilbank et al., 2006), resulting in an increased number of S/C (Macmillan et al., 1996; Roche et al., 2000; Royal et al., 2000; Lucy, 2001).

\section{Reproductive Performance of Dairy Cows in Five Farmer Groups}

The proportion of cows conceived within $350 \mathrm{~d}$ postpartum of a total of 82 cows in five commercial dairy farmer groups, was $75.6 \%$. Days in milk at first $\mathrm{AI}$, first $\mathrm{AI}$ conception rate, and calving to conception interval were $62.5 \pm 19.3 \mathrm{~d}, 0 \%, 202.8 \pm 150.0 \mathrm{~d}$, respectively (Table 2).

Days in milk at first AI of the 82 cows involved in the current study seemed comparable with previous studies (Lamming \& Darwash, 1998; Lopez-Gatius, 2003; Santos et al., 2004; Yusuf et al., 2010a). However, first AI conception rate and calving to conception interval showed much lower. This was probably caused by heat stress due to the hot humid weather in tropical condition, resulting in lower first AI conception rate and longer calving to conception interval. Cows suffering from heat stress had a lower oocyte quality (Sartori et al., 2002; Leroy et al., 2008), reduced duration and intensity of estrus, altered follicular development, and impaired embryonic development (Jordan, 2003), higher incidence of abnormal resumption of postpartum ovarian cycles, lower heat detection rate, lower first AI conception rate, and lower pregnancy rate (Kornmatitsuk et al., 2008). Therefore, in future, prevention of reproductive disorders such as repeat breeding will be required for both reproductive efficiency and animal welfare (Nakada, 2006).

\section{CONCLUSION}

There was a high incidence of repeat breeding in small holder dairy system under tropical condition, thus reduced reproductive performance.

\section{ACKNOWLEDGMENT}

The authors gratefully acknowledge all the dairy farmers in Sinjai Regency for their help and cooperation during the study period.

\section{REFERENCES}

Båge, R., H. Gustafsson, B. Larsson, M. Forsberg, \& H. Rodríguez-Martínez. 2002. Repeat breeding in dairy heifers: follicular dynamics and estrous cycle characteristics in relation to sexual hormone patterns. Theriogenology 57: 2257-2269. DOI:10.1016/S0093-691X(02)00840-3

Bartlett, P.C.,J.H. Kirk, \& E. C. Mather. 1986. Repeated insemination in Michigan Holstein Friesian cattle: incidence, descriptive epidemiology and estimated economic impact. Theri- 
ogenology 26: 309-322. DOI:10.1016/0093-691X(86)90150-0

Britt, J. H. 1994. Follicular development and fertility: potential impacts of negative energy balance. Proc Nat Reprod Symposim, Pittsburgh, PA, Sept 22-23, pp: 103-112.

Bulman, D. C. \& G. E. Lamming. 1978. Milk progesterone levels in relation to conception, repeat breeding and factors influencing acyclicity in dairy cows. J Reprod Fertil 54: 447-458. DOI: 10.1530/jrf.0.0540447

Butler, W. R. 2000. Nutritional interactions with reproductive performance in dairy cattle. Anim Reprod Sci 60-61: 449457. DOI: 10.1016/S0378-4320(00)00076-2

Dochi, O., K. Takahashi, T. Hirai, H. Hayakawa, M. Tanisawa, Y. Yamamoto, \& H. Koyama. 2008. The use of embryo transfer to produce pregnancies in repeat-breeding dairy cattle. Theriogenology 69: 124-128. DOI: 10.1016/j.theriog enology.2007.09.001

Gustafsson, H. 1998. Studies on follicular dynamics and hormonal asynchrony around ovulation as a potential cause of repeat breeding. Reprod. Dom. Anim. 33: 139-140. DOI: 10.1111/j.1439-0531.1998.tb01331.x

Hallap, T., S. Nagy, Ü. Jaakma, A. Johannisson, \& H. Rodriguez-Martinez. 2006. Usefulness of a triple fluorochrome combination Merocyanine 540/Yo-Pro 1/Hoechst 33342 in assessing membrane stability of viable frozen-thawed spermatozoa from Estonian Holstein AI bulls. Theriogenology 65: 1122-1136. DOI: 10.1016/j.theriogenology.2005.07.009

Heuwieser, W., P. A. Oltenacu, A. J. Lednor, \& R. H. Foote. 1997. Evaluation of different protocols for prostaglandin synchronization to improve reproductive performance in dairy herds with low estrus detection efficiency. J Dairy Sci 80: 2766-2774. DOI: 10.3168/jds.S0022-0302(97)76239-8

Jordan, E. R. 2003. Effects of heat stress on reproduction. J Dairy Sci 86: (E. Suppl.) E104-E114. DOI: 10.3168/jds.S00220302(03)74043-0

Katagiri, S. \& Y. Takahashi. 2004. Changes in EGF concentrations during estrous cycle in bovine endometrium and their alterations in repeat breeder cows. Theriogenology 62: 103-112. DOI: 10.1016/j.theriogenology.2003.08.019

Kimura, M., T. Nakao, M. Moriyoshi, \& K. Kawata. 1987. Luteal phase deficiency as a possible causes of repeat breeding in dairy cows. Br. Vet. J. 143: 560-566.

Kornmatitsuk, B., P. Chantaraprateep, S. Kornmatitsuk, \& H. Kindahl. 2008. Different types of postpartum luteal activity affected by the exposure of heat stress and subsequent reproductive performance in Holstein lactating cows. Reprod Dom Anim 43: 515-519. DOI: 10.1111/j.14390531.2007.00945.x

Lamming, G. E. \& A. O. Darwash. 1998. The use of milk progesterone profiles to characterise components of subfertility in milked dairy cows. Anim Reprod Sci 52: 175-190. DOI: 10.1016/S0378-4320(98)00099-2

Leroy, J. L. M. R., A. Van Soom, G. Opsomer, I. G. F. Goovaerts, \& P. E. J. Bols. 2008. Reduced fertility in high-yielding dairy cows: are the oocyte and embryo in danger? Part II. Mechanisms linking nutrition and reduced oocyte and embryo quality in high-yielding dairy cows. Reprod Dom Anim 43: 623-632. DOI: 10.1111/j.1439-0531.2007.00960.x

Lopez-Gatius, F. 2003. Is fertility declining in dairy cattle? A retrospective study in northeastern Spain. Theriogenology 60: 89-99. DOI: 10.1016/S0093-691X(02)01359-6

Lopez-Gatius, F., J. L. Yaniz, P. Santolaria, K. Murugavel, R. Guijarro, E. Calvo, \& M. Lopez-Bejar. 2004. Reproductive performance of lactating dairy cows treated with cloprostenol at the time of insemination. Theriogenology 62: 677689. DOI: $10.1016 / j$.theriogenology.2003.11.014

Lucy, M. C. 2001. Reproductive loss in high-producing dairy cattle: where will it end? J Dairy Sci $84: 1277-1293$. DOI: 10.3168/jds.S0022-0302(01)70158-0

Macmillan, K. L., I. J. Lean, \& C. T. Westwood. 1996. The effects of lactation on the fertility of dairy cows. Aust Vet J 73: 141147. DOI: 10.1111/j.1751-0813.1996.tb10007.x

Morrell, J. M. 2006. Update on semen technologies for animal breeding. Reprod Dom Anim 41: 63-67. DOI: 10.1111/ j.1439-0531.2006.00621.x

Moss, N., I. J. Lean, S. W. J. Reid, \& D. R. Hodgson. 2002. Risk factors for repeat-breeder syndrome in New South Wales dairy cows. Prev Vet Med 54: 91-103. DOI: 10.1016/S01675877(02)00016-8

Nakada, K. 2006. How to improve reproductive efficacy from now in Japan? Find out the factors of late lactation to predict postpartum reproductive diseases. J Reprod Dev 52: 177-183. DOI:10.1262/jrd.17090

Pursley, J. R., R. W. Silcox, \& M. C. Wiltbank. 1998. Effect of time of artificial insemination on pregnancy rates, calving rates, pregnancy loss, and gender ratio after synchronization of ovulation in lactating dairy cows. J Dairy Sci 81: 2139-2144. DOI: 10.3168/jds.S0022-0302(98)75790-X

Roberts, S. J. 1986. Veterinary Obstetrics and Genital Diseases (Theriogenology). Woodstock, Vermont 05091.

Roche, J. F., D. Mackey, \& M. D. Diskin. 2000. Reproductive management of postpartum cows. Anim Reprod Sci 60-61: 703-712. DOI: 10.1016/S0378-4320(00)00107-X

Royal, M. D., A. O. Darwash, A. P. F. Flint, R. Webb, J. A. Woolliams, \& G. E. Lamming. 2000. Declining fertility in dairy cattle: changes in traditional and endocrine parameters of fertility. Anim Sci 70: 487-501.

Santos, J. E. P., R. L. A. Cerri, M. A. Ballou, G. E. Higginbotham, \& J. H. Kirk. 2004. Effect of timing of first clinical mastitis occurence on lactational and reproductive performance of Holstein dairy cows. Anim Reprod Sci 80: 31-45. DOI: 10.1016/S0378-4320(03)00133-7

Sartori, R., R. Sartor-Bergfelt, S. A. Mertens, J. N. Guenther, J. J. Parrish, \& M. C. Wiltbank. 2002. Fertilization and early embryonic development in heifers and lactating cows in summer and lactating and dry cows in winter. J Dairy Sci 85: 2803-2812. DOI: 10.3168/jds.S0022-0302(02)74367-1

Silvia, W. J. 1994. Embryonic mortality and repeat breeder cows. 1994. Proceedings, National Reproduction Symposium, 27 $7^{\text {th }}$ Annual Conference of the American Association of Bovine Practitioners, Pittsburgh, PA. pp: 151-160.

Wiltbank, M. C., H. Lopez, R. Sartori, S. Sangsritavong, \& A. Gumen. 2006. Changes in reproductive physiology of lactating dairy cows due to elevated steroid metabolism. Theriogenology 65: 17-29. DOI: 10.1016/j.theriogenology.2 005.10.003

Yusuf, M., T. Nakao, R. M. S. B. K. Ranasinghe, G. Gautam, S. T. Long, C. Yoshida, K. Koike, \& A. Hayashi. 2010a. Reproductive performance of repeat breeders in dairy herds. Theriogenology 73: 1220-1229. DOI: 10.1016/j.theriogenology.2010.01.016

Yusuf, M., T. Nakao, S. T. Long, \& G. Gautam. 2010b. Analysis of some factors affecting fertility levels in a high-producing dairy herd in south-western Japan. Anim Sci J 81: 467474. DOI: $10.1111 /$ j.1740-0929.2010.00764.x 